\title{
New data on karyotype, spermatogenesis and ovarian trophocyte ploidy in three aquatic bug species of the families Naucoridae, Notonectidae, and Belostomatidae (Nepomorpha, Heteroptera)
}

\author{
Desislava Stoianova', Nikolay Simov², Manh Quang Vu \\ Duc Minh Nguyen ${ }^{4}$, Snejana Grozeva'
}

I Institute of Biodiversity and Ecosystem Research, Bulgarian Academy of Sciences, 1 Tsar Osvoboditel Blvd., Sofia 1000, Bulgaria 2 National Museum of Natural History, Bulgarian Academy of Sciences, 1 Tsar Osvoboditel Blvd., Sofia 1000, Bulgaria 3 Hanoi National University of Education (HNUE), 136 Xuan Thuy Rd., DHSP Cau Giay; clo Ho Chi Minh City University of Food Industry, 140 Le Trong Tan St., Tan Phu, Ho Chi Minh City, Vietnam 4 Institute of Ecology and Works Protection, Hanoi, Vietnam

Corresponding author: Desislava Stoianova (d.st.stoianova@gmail.com)

Academic editor: S. Nokkala | Received 22 November 2019 | Accepted 7 February 2020 | Published 5 March 2020

http://zoobank.org/46374995-A8A3-4912-88B3-7590A179274F

Citation: Stoianova D, Simov N, Vu MQ, Nguyen DM, Grozeva S (2020) New data on karyotype, spermatogenesis and ovarian trophocyte ploidy in three aquatic bug species of the families Naucoridae, Notonectidae, and Belostomatidae (Nepomorpha, Heteroptera). Comparative Cytogenetics 14(1): 139-156. https://doi.org/10.3897/CompCytogen. v14i1.48709

\begin{abstract}
We report the karyotype, some aspects of spermatogenesis, and ovarian trophocytes ploidy in three aquatic bug species: Ilyocoris cimicoides (Linnaeus, 1758), Notonecta glauca Linnaeus, 1758, and Diplonychus rusticus Fabricius, 1871 from previously unexplored regions - South Europe (Bulgaria) and Southeast Asia (Vietnam). Our results add considerable support for the published karyotype data for these species. In $I$. cimicoides, we observed achiasmate male meiosis - the first report of achiasmy for the family Naucoridae. More comprehensive cytogenetic studies in other species of the Naucoridae are required to elucidate the role of achiasmy as a character in the systematics of the family.

Our observations on the association between phases of spermatogenesis and developmental stages in $I$. cimicoides and $N$. glauca differ from the previously published data. In these species, we assume that the spermatogenesis phases are not strongly associated with certain developmental stages. For further cytogenetic studies (on the Balkan Peninsula), we recommend July as the most appropriate month for collection of $I$. cimicoides and $N$. glauca.
\end{abstract}

Copyright Desislava Stoianova et al. This is an open access article distributed under the terms of the Creative Commons Attribution License (CC BY 4.0), which permits unrestricted use, distribution, and reproduction in any medium, provided the original author and source are credited. 
In the ovaries of both species, we studied the level of ploidy in metaphase and interphase trophocytes. In $I$. cimicoides, diploid and tetraploid metaphase trophocytes were found. Heteropycnotic elements, observed in interphase trophocytes of this species, represented the $\mathrm{X}$ chromosomes. It allowed us to determine the trophocytes ploidy at interphase ( $2 \mathrm{n}$ was repeated up to 16 times). The situation with $N$. glauca was different. The metaphase trophocytes were diploid and we were not able to determine the ploidy of interphase trophocytes since such conspicuous heteropycnotic elements were not found. The scarce data available suggest a tendency for a low level of trophocyte ploidy in the basal infraorders (Nepomorpha and Gerromorpha) and for a high level in the more advanced Pentatomomorpha. Data about this character in species from other infraorders are needed to confirm that tendency.

\section{Keywords}

achiasmate male meiosis (achiasmy), B-chromosomes, karyotype, nurse cells, South Europe and Southeast Asia, Diplonychus rusticus, Ilyocoris cimicoides, Notonecta glauca

\section{Introduction}

Ilyocoris cimicoides (Linnaeus, 1758), Notonecta glauca Linnaeus, 1758, and Diplonychus rusticus Fabricius, 1871 are common predators in freshwater basins. The first two species are broadly distributed across the Palearctic region. Ilyocoris cimicoides (Naucoridae) inhabits most of Europe and Asia from Anatolia to Siberia and North China (Fent et al. 2011). Notonecta glauca (Notonectidae) occurs in Europe, North Africa, western parts of Central Asia, reaching northwest China (Polhemus 1995, Linnavuori and Hosseini 2000, Kanyukova 2006, Fent et al. 2011). Diplonychus rusticus (Belostomatidae) is widespread in the warmer regions of India, Sri Lanka, Southeast Asia, Malaysia, Sumatra, Java, Borneo, Sulawesi, Philippines, New Guinea, China, and Japan (Chen et al. 2005, Polhemus and Polhemus 2013). Although these three species have broad ranges, karyotype data for them have been published only from few regions: I. cimicoides - northern of the Danube River (Steopoe 1929); N. glauca - England (Browne 1916, Angus et al. 2004), Finland (Halkka 1956), Netherlands (Pantel and Sinety 1906), D. rusticus - India (Bawa 1953, Jande 1959). A recently described variation in chromosome number between different populations of two broadly distributed species of Nepomorpha (Angus et al. 2017) have raised the question if there are such cytogenetic differences between populations of other broadly distributed species (I. cimicoides, N. glauca, and D. rusticus).

In many insect species, spermatogenesis completes at the final preimaginal developmental stage, so that the testes of adults contain only spermatids/spermatozoa (Dumser 1980, Gillot 1995). In Heteroptera, adults are traditionally used for cytogenetic studies as at this stage, accurate species identification is easy and spermatogenesis still occurs (e.g. Nokkala and Nokkala 1999, Grozeva and Nokkala 2003, Lanzone and Souza 2006, Castanhole et al. 2008, Golub et al. 2018, Grozeva et al. 2019, for extensive bibliography see Papeschi and Bressa 2006). However, in last (V) instar and adults of nepomorphan species $I$. cimicoides and $N$. glauca, testes were shown to con- 
tain only spermatids/spermatozoa. Spermatogenesis has been observed only in earlier developmental stages: instar III and IV nymphs of I. cimicoides (in Papáček and Gelbič 1989) and instar IV and V of N. glauca (Papáček and Soldán 1992). Spermatogenesis was not the focus of the cited studies; the authors' comments are based only on histological analysis of testes.

A detailed cytogenetic analysis could elucidate the association of certain stages of meiosis with definite instars. Such data would be useful in further cytogenetic studies of these species (e.g. to collect the most appropriate developmental stage with meiotic or mitotic divisions).

In hemipteran species (incl. Heteroptera), the ovaries consist of meroistic telotrophic ovarioles, characterised by a tropharium in the apex and a vitellarium in the basal part (Ma and Ramaswamy 1987). The organisation of the tropharium has been studied in species of each of the infraorders of Heteroptera but Enicocephalomorpha (Eschenberg and Dunlap 1966, Heming-van Battum and Heming 1986, Bilinski et al. 1990, Jawale and Ranade 1990, Simiczyjew et al. 1996, Štys et al. 1998, more references in Štys et al. 1998 and in Simiczyjew et al. 1998). Significant differences in the species of the basal infraorders compared to those of the more advanced infraorders have been found (Simiczyjew et al. 1998). Unlike the organisation of the tropharium, very little attention has been given to the ploidy of trophocytes (nurse cells). The level of trophocyte ploidy in heteropteran ovarioles has been reported only for three species of two infraorders. Choi and Nagl (1977) measured diploid DNA content increase in trophocytes of Gerris najas (De Geer, 1773) - 16-fold increase; Cave (1975) - in Oncopeltus fasciatus (Dallas, 1852) - 128-fold increase; Dittmann et al. (1984) in Dysdercus intermedins Distant, 1902) - 124-fold increase. The first species ( $G$. najas) belongs to one of the basal (Gerromorpha), while the last two species - to one of the most advanced (Pentatomomorpha) infraorders. In the ovaries of insects of another hemipteran group - aphids, the level of trophocyte ploidy is suggested to be species specific (Michalik et al. 2013), but for the true bugs there is no confirmation of that.

The aim of the present cytogenetic study was to examine Ilyocoris cimicoides, Notonecta glauca, and Diplonychus rusticus originating from previously unexplored regions - South Europe (Bulgaria) and Southeast Asia (Vietnam), in order to 1) check cytogenetic differences between populations; 2) analyse the relationship between the developmental stages and the phases of spermatogenesis in testes for I. cimicoides and $N$. glauca; and 3) determine the ploidy level of trophocytes in ovaries on the example of I. cimicoides and $N$. glauca.

\section{Material and methods}

Specimens of Diplonychus rusticus (Belostomatidae) (4 males) were collected in September 2018 from Vietnam: Ca Mau Province, Tran Van Thoi District, Tran Hoi commune, U Minh Ha National Park, 09.22521N, 104.95898E (Fig. 1). Specimens 


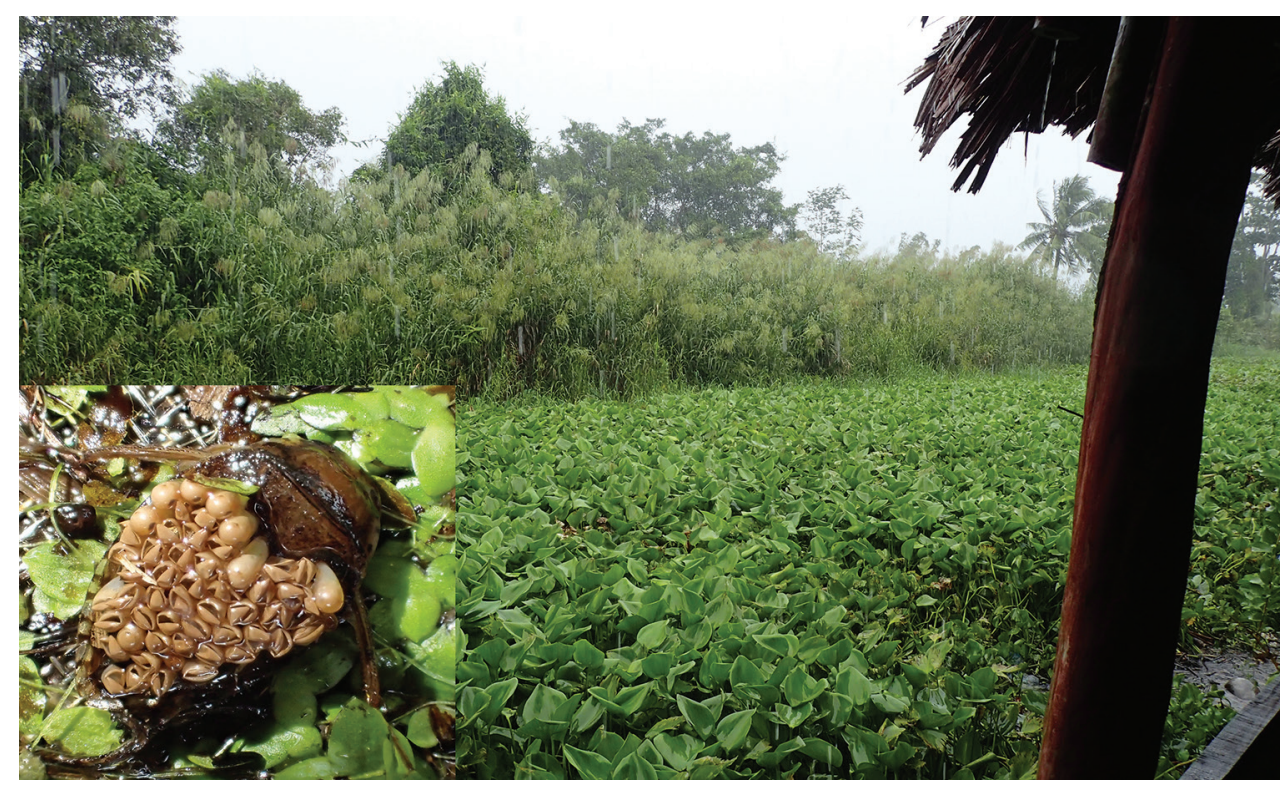

Figure I. Diplonychus rusticus, male carrying eggs and typical habitat of the species in U Minh $\mathrm{Ha} \mathrm{Na-}$ tional Park, Ca Mau Province, Vietnam.

of Ilyocoris cimicoides (Naucoridae) (16 males, 7 females) and Notonecta glauca (Notonectidae) (19 males and 6 females) were collected during the period September 2018-August 2019 from three different localities in Bulgaria: Pernik Province, Choklyovo blato Marsh, 42.40252N, 22.82234E; Sofia Province, artificial pond in a park in the City of Sofia, 42.66355N, 23.30742E; Sofia Province, pools near the Town of Ihtiman, 42.459837N, 23.804966E. For cytogenetic studies, the insects were fixed in the field in 3:1 fixative (96\% ethanol: glacial acetic acid). The gonads were dissected out and squashed in a drop of $45 \%$ acetic acid. The coverslips were removed using dry ice. Slides were dehydrated in fresh fixative (3:1) and air-dried. The preparations were stained using the Schiff-Giemsa (Grozeva and Nokkala 1996) and C-banding (Grozeva et al. 2004) method. The chromosomal location of $18 \mathrm{~S}$ rDNA clusters was determined by the well-known FISH protocol (Grozeva et al. 2011, 2015, 2019, Golub et al. 2019).

Giemsa stained preparations were analysed under an Axio Scope A1 - Carl Zeiss Microscope) at 100× magnification and documented with a ProgResMFcool - Jenoptik AG digital camera. FISH preparations were analysed under a Leica DM 6000 B microscope and images were acquired using a Leica DFC 345 FX camera and Leica Application Suite 3.7 software with an Image Overlay module.

The specimens and the chromosome preparations used for this study are stored at the Lab of Cytotaxonomy and Evolution, Institute of Biodiversity and Ecosystem Research, BAS (Sofia, Bulgaria). 


\section{Results and discussion}

\section{Description of the karyotype \\ Ilyocoris cimicoides, $2 \mathrm{n}=51(48 \mathrm{~A}+2 \mathrm{~m}+\mathrm{X}) \curvearrowright$}

The morphology of the testes of the examined males and the ovaries of the females matched the descriptions given by Papáček and Gelbič (1989) and Papáček et al. (1997), respectively.

Like all heteropteran species (Ueshima 1979, Papeschi and Bressa 2006, Kuznetsova et al. 2011), the chromosomes of this species are holokinetic - without localized centromere. In studied male and female nymphs, mitotic metaphases consisted of 48 autosomes (Figs 2 a, b, 3). Except the 48 autosomes, the karyotype included a pair of very small $\mathrm{m}$-chromosomes (see below the description of the meiotic metaphase I), difficult for observation in mitotic cells. The $\mathrm{X}$ chromosomes were the largest chromosomes of the complement. At spermatogonial metaphase, the X chromosome displayed interstitial heterochromatin blocks after C-banding (Fig. 2b). In the early condensation stage (late meiotic prophase), we observed 24 bivalents consisting of two sideby-side aligned chromosomes without any sign of chiasmata between them, a pair of $\mathrm{m}$-chromosome univalents, and the heteropycnotic X chromosome, which usually appeared close to the nucleolus (Fig. 4). At the late condensation stage, the X still tended to be close to the nucleolus (Fig. 5a, b). At metaphase I (MI), the autosomal bivalents were similar in size. Most of them formed a ring. The m-chromosome pair and some of the autosomal bivalents laid inside the ring (Fig. 6). The X chromosome was usually seen close to the periphery of the ring. The post-reduction for the sex chromosomes in male meiosis is another specific cytogenetic character of Heteroptera being typical for the majority of the studied species and higher taxa of this group (Ueshima 1979, Kuznetsova et al. 2011). Such was the case in I. cimicoides: the X was observed in all the examined anaphase I (AI) (Fig. 7 a-c), telophase I (TI) nuclei (Fig. 8) and in all daughter cells at metaphase II (MII) (Fig. 9). At AI, it was easy to distinguish the mchromosomes, which were going ahead of the set (Figs 7, 8). At MII, only the large X could be recognized reliably (Fig. 9). At telophase II (TII), the second (equational for the autosomes but reductional for the sex chromosomes) division resulted in two types of daughter cells - with and without X chromosome (Fig. 10).

Cytogenetic data on I. cimicoides have been published by Divaz (1915) and Steopoe (1929). Divaz (1915) studied the spermatogenesis of I. cimicoides from Serbia, but he did not actually deal with the karyotype: he focused on the presence and behaviour of specific chromatophilic bodies ("corpuscules archoplasmiques"). Our results confirmed the chromosome formula of $2 n=51(48 A+2 m+X)$, and the chromosomes behaviour for male I. cimicoides reported by Steopoe (1929), based on specimens (without information of their developmental stage) collected north of the Danube River. These authors did not mention anything about the formation of chiasmata. In the present study, we provide the first report for achiasmate male 


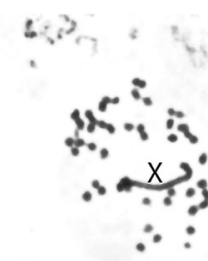

$2 \mathrm{a}$

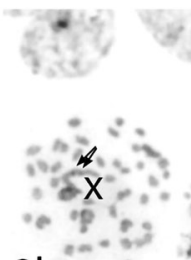

$2 b$

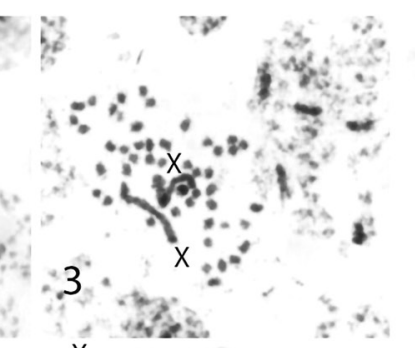

4

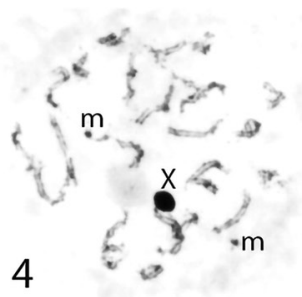

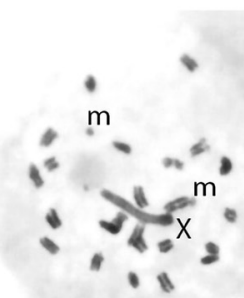

$5 a$

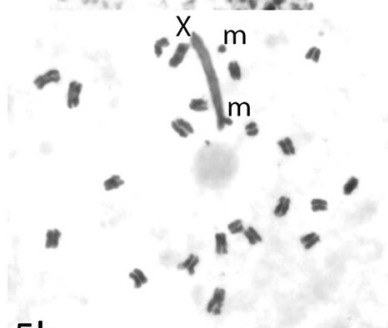

$5 b$,

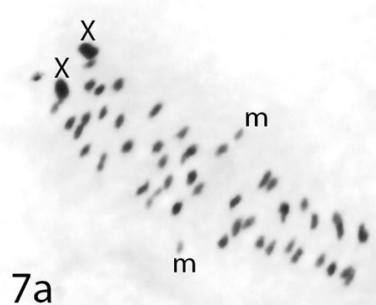

$7 a$
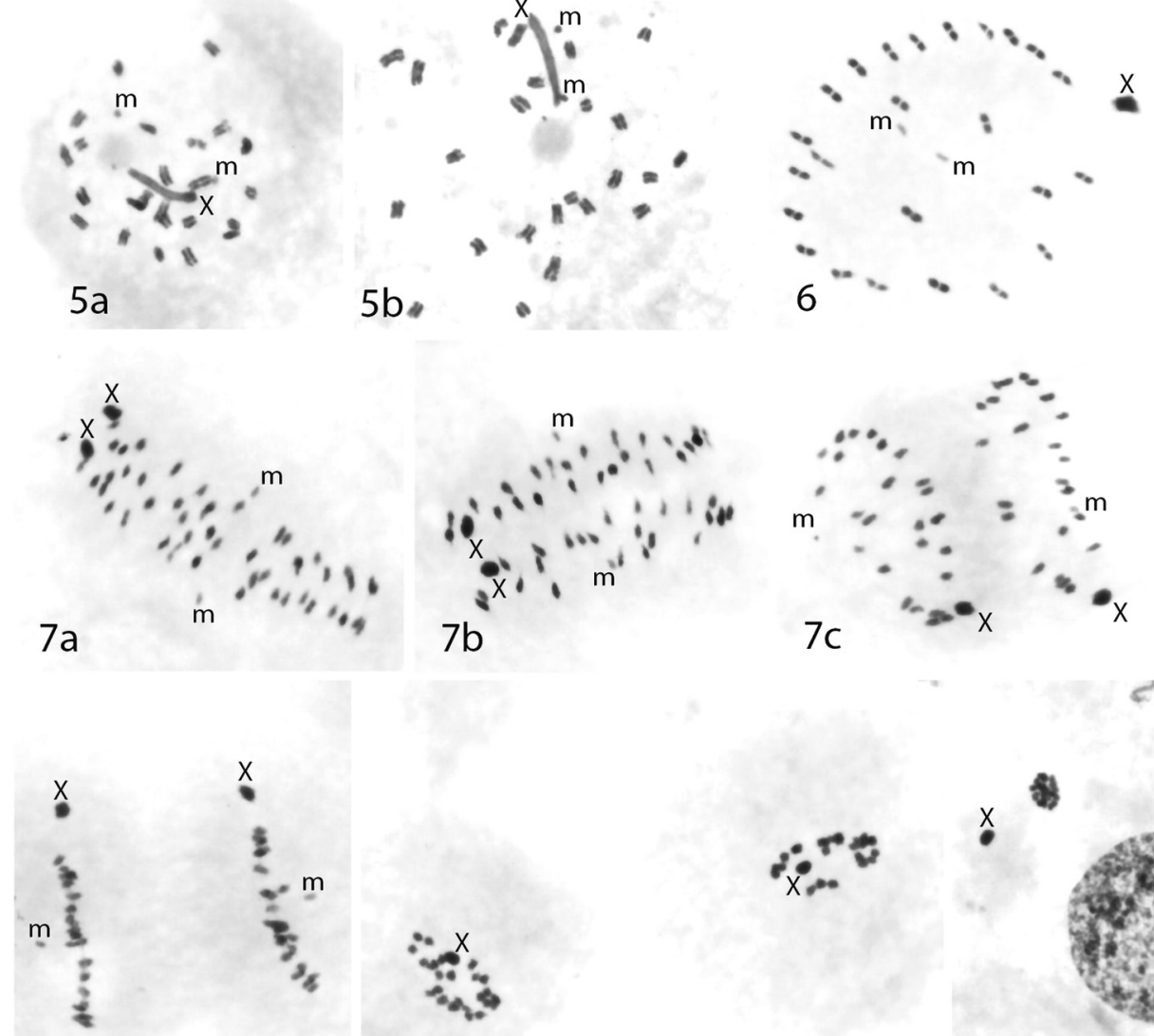

8

9
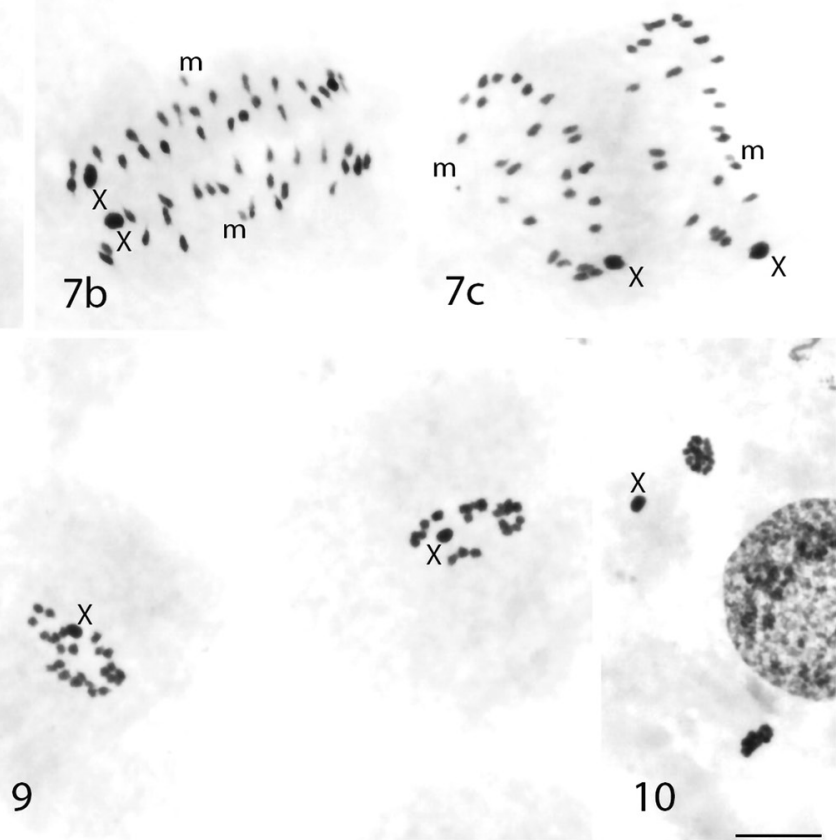

Figures 2-10. Ilyocoris cimicoides (testis/ovary): Schiff-Giemsa (2a, 3-10), C-banding (2b) 2a, b spermatogonial metaphase (arrows indicate heterochromatin blocks) $\mathbf{3}$ oogonial metaphase 4-8 primary spermatocytes: $\mathbf{4}$ early condensation stage $\mathbf{5 a}$, b late condensation stage $\mathbf{6}$ metaphase I $\mathbf{7}$ a-c anaphase I $\mathbf{8}$ telophase I 9, $\mathbf{1 0}$ secondary spermatocytes: $\mathbf{9}$ metaphase II $\mathbf{I}$ two telophases II - one with X, another without X. Scale bar: $10 \mu \mathrm{m}$.

meiosis in I. cimicoides and in the whole family Naucoridae. The achiasmate type of meiosis, called also "achiasmy" (Satomura et al. 2019), as a rule, is restricted to the heterogametic sex (White 1973). Hitherto, achiasmate male meiosis has been found 
in eight other families of three Heteroptera infraorders, namely Cimicomorpha: Anthocoridae, Microphysidae, Cimicidae, Miridae, and Nabidae; Leptopodomorpha: Saldidae; Nepomorpha: Micronectidae and Corixidae (Stoianova et al. 2015, more references in Kuznetsova et al. 2011). Most of the studied families seem to be homogenous in respect to the presence/absence of chiasmata. Based on the cited data it is suggested that in Heteroptera achiasmy is a stable cytogenetic characteristic at the family level (Grozeva et al. 2008, Kuznetsova et al. 2011). However, heterogeneity in respect to this character has been observed in family Corixidae (Nepomorpha) (Stoianova et al. 2015). Achiasmy is reported for two Cymatia species, while the rest examined species of the Corixidae display chiasmata. The achiasmy in I. cimicoides (present study) reveals the heterogeneity of the Naucoridae in respect to this character. Hitherto, cytogenetic studies have been published for eight other naucorid species (Papeschi 1992, for more references see Ueshima 1979). Two of them, Pelocoris lautus Berg, 1879 and P. binotulatus (Stål, 1862), were shown to display chiasmate meiosis in males (Papeschi 1992), while for another six species no information on the presence/absence of chiasmata has been provided (for references see Ueshima 1979). It is noteworthy that in another insect order (Diptera) heterogeneity in the

type of male meiosis (achiasmate/chiasmate) has been reported even at genus level (see Satomura et al. 2019). Taking into consideration these new findings, more comprehensive cytogenetic studies in other species of the family Naucoridae are required to elucidate the type of meiosis (chiasmate/achiasmate) as a character in the systematics of the family.

\section{Diplonychus rusticus, $2 \mathrm{n}=28(24 \mathrm{~A}+2 \mathrm{~m}+\mathrm{XY}) \circlearrowright$}

The internal reproductive system of the examined adult males confirmed the morphological descriptions given for Diplonychus rusticus by Pendergrast (1957: as Sphaerodema rusticum Fabricius, 1871). Every colorless testis consisted of one more or less spherical follicle, decreasing in diameter from the apex to the vas deferens, which expanded to a vesicula seminalis. Such structure of the male reproductive system was described and illustrated well in another Belostomatidae species - Lethocerus patruelis (Stål, 1854) (Grozeva et al. 2013).

Chromosome complement in males of $D$. rusticus (as $S$. rusticum) from India was published as $2 \mathrm{n}=28(24 \mathrm{~A}+2 \mathrm{~m}+\mathrm{XY})$, together with drawings of the chromosomes at different stages of spermatogenesis (Bawa 1953, Jande 1959). These authors claim a symmetric karyotype and describe in detail all stages of spermatogenesis: spermatogonial mitosis and the behaviour of the chromosomes during both meiotic divisions.

We studied males of this species from Vietnam, collected in U Minh Ha National Park. Spermatogonial metaphases resembled those of D. rusticus, D. annulatus (Fabricius, 1781) and D. molestus (Dufour, 1863) (as D. subrhombeus (Mayr, 1871)) studied from India (Bawa 1953, Jande 1959). They consisted of 28 chromosomes (Fig. 11) but it was difficult to identify individual chromosomes in the set. At early spermatogonial 


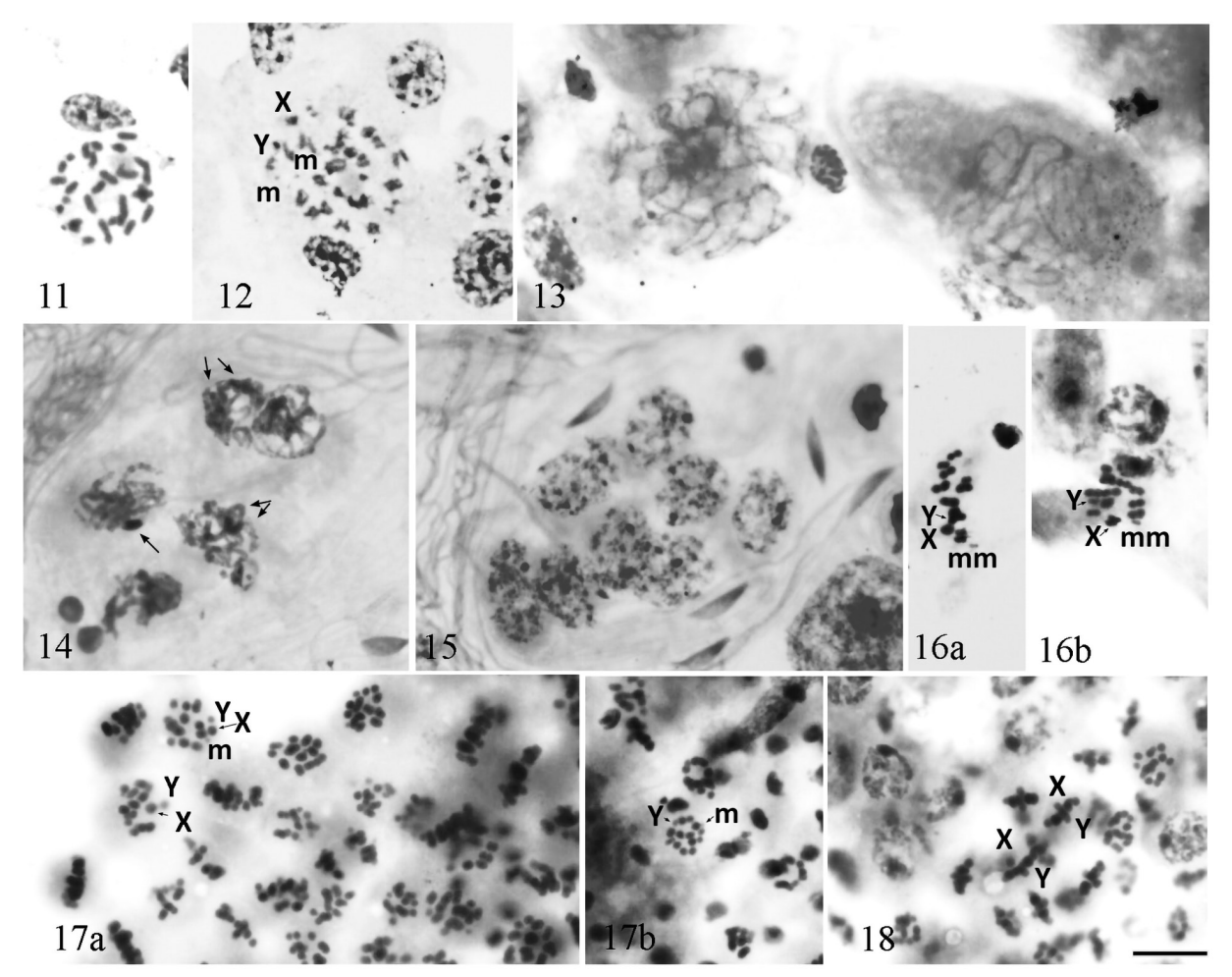

Figures II-18. Diplonychus rusticus (testis) II spermatogonial metaphase $\mathbf{I}$ spermatogonial anaphase 13-16 primary spermatocytes: $\mathbf{1 3}$ leptotene $\mathbf{1 4}$ pachytene $\mathbf{1 5}$ diffuse stage $\mathbf{1 6} \mathbf{6}$, $\mathbf{b}$ metaphase I I 7, 18 secondary spermatocytes: 17 a, b metaphase II 18 anaphase II. Scale bar:10 $\mu \mathrm{m}$.

anaphase, the chromosomes were split in chromatids, lying in parallel (Fig. 12), which is the case for holokinetic chromosomes (for instance, Lukhtanov et al. 2019) and one could recognize the X, Y and m-chromosomes. At leptotene (Fig. 13), long and thin chromosomes began to thicken, the sister chromatids were not visible as separate entities. At pachytene (Fig. 14), one or two heteropycnotic bodies of the sex chromosome heterochromatin could be observed. During the diffuse stage, the sex chromosomes were more often associated with each other (Fig. 15). At MI, 12 bivalents, two sex chromosomes as univalents, and a pseudobivalent of the m-chromosomes could be seen (Fig. 16 a, b). At MII, every plate consisted of 12 autosomes, a pseudobivalent of the sex chromosomes, and one m-chromosome (Fig. 17 a, b). The first meiotic division was thus reductional for the autosomes and equational for the sex chromosomes. At AII, the sex chromosomes were going ahead to the poles (Fig. 18). The study of males from Vietnam fully confirmed the observations and description on the spermatogenesis of this species from India (Bawa 1953, Jande 1959). Here, we provide for the first time, photographs of the spermatogenesis stages for D. rusticus. 
Notonecta glauca, $2 \mathrm{n}=24(20 \mathrm{~A}+2 \mathrm{~m}+\mathrm{XY}) \curvearrowright$

The ovaria of the females and the testes of the males examined matched the morphological descriptions given by Papáček and Soldán (1987, 1992, respectively).

In gonads of females and males, we found mitotic metaphase plates with 24 chromosomes including two sex chromosomes (Fig. 19 a, c). As an exception, only two mitotic metaphase plates with 26 elements were found: one in a ovariole (Fig. $19 \mathrm{~b}$ ), in which we found mitotic metaphase plates with 24 chromosomes and one in a testis (Fig. $19 \mathrm{~d}$ ), in which we found mitotic metaphase plates with 24 chromosomes.

In adults collected in July, we found the advanced stages of spermatogenesis, from MI (Fig. 20) to AII (Fig. 23). At MI, 10 autosomal bivalents and the X and Y chromosomes formed a ring with a pseudobivalent of m-chromosomes in it (Fig. 20). It

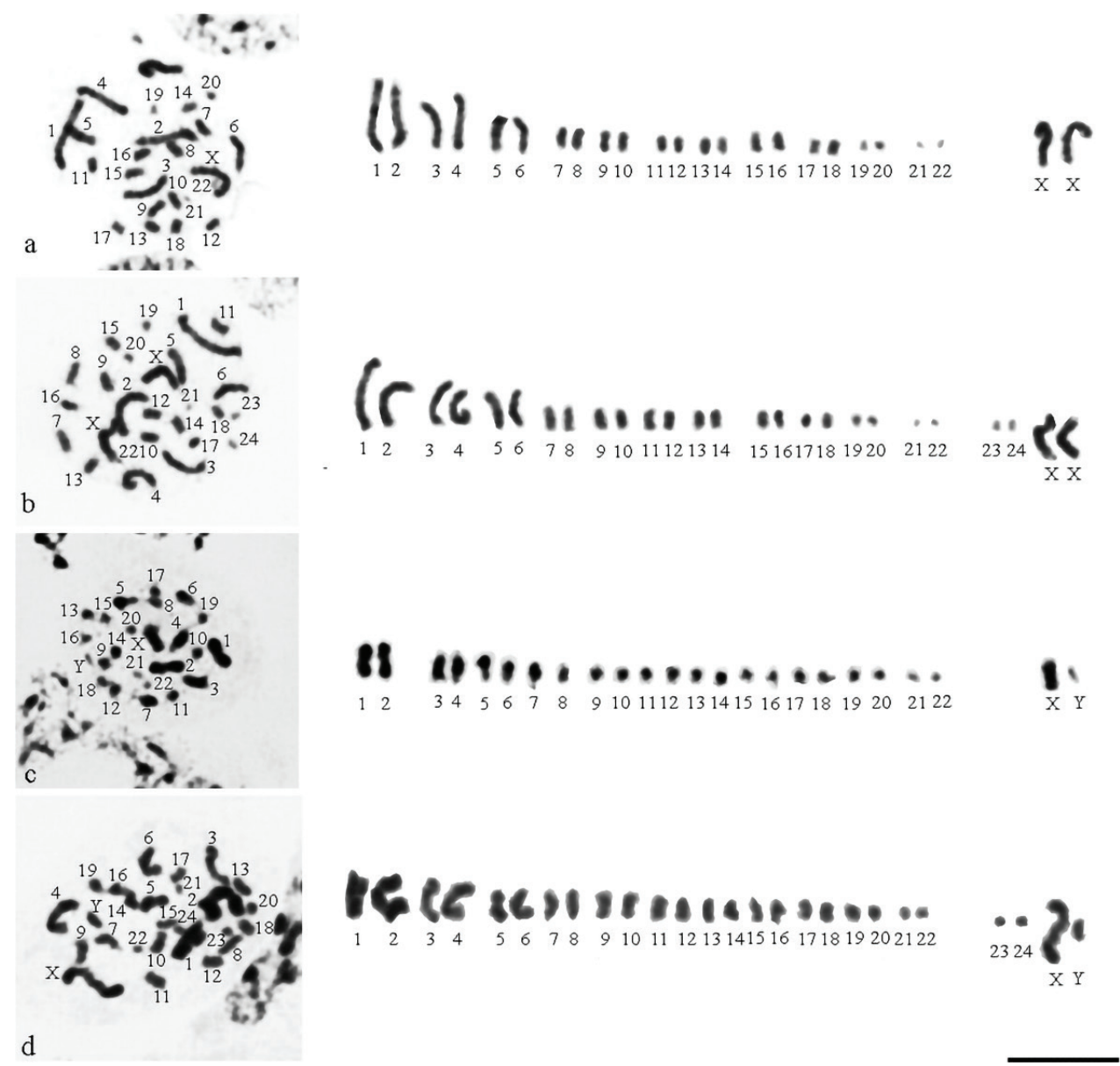

Figures 19. Notonecta glauca (testis/ovary) a, b mitotic metaphase in a ovariole: a with 24 chromosome elements $\mathbf{b}$ with 26 chromosome elements $\mathbf{c}, \mathbf{d}$ mitotic metaphase in a testis: $\mathbf{c}$ with 24 chromosome elements $\mathbf{d}$ with 26 chromosome elements. Scale bar: $10 \mu \mathrm{m}$. 


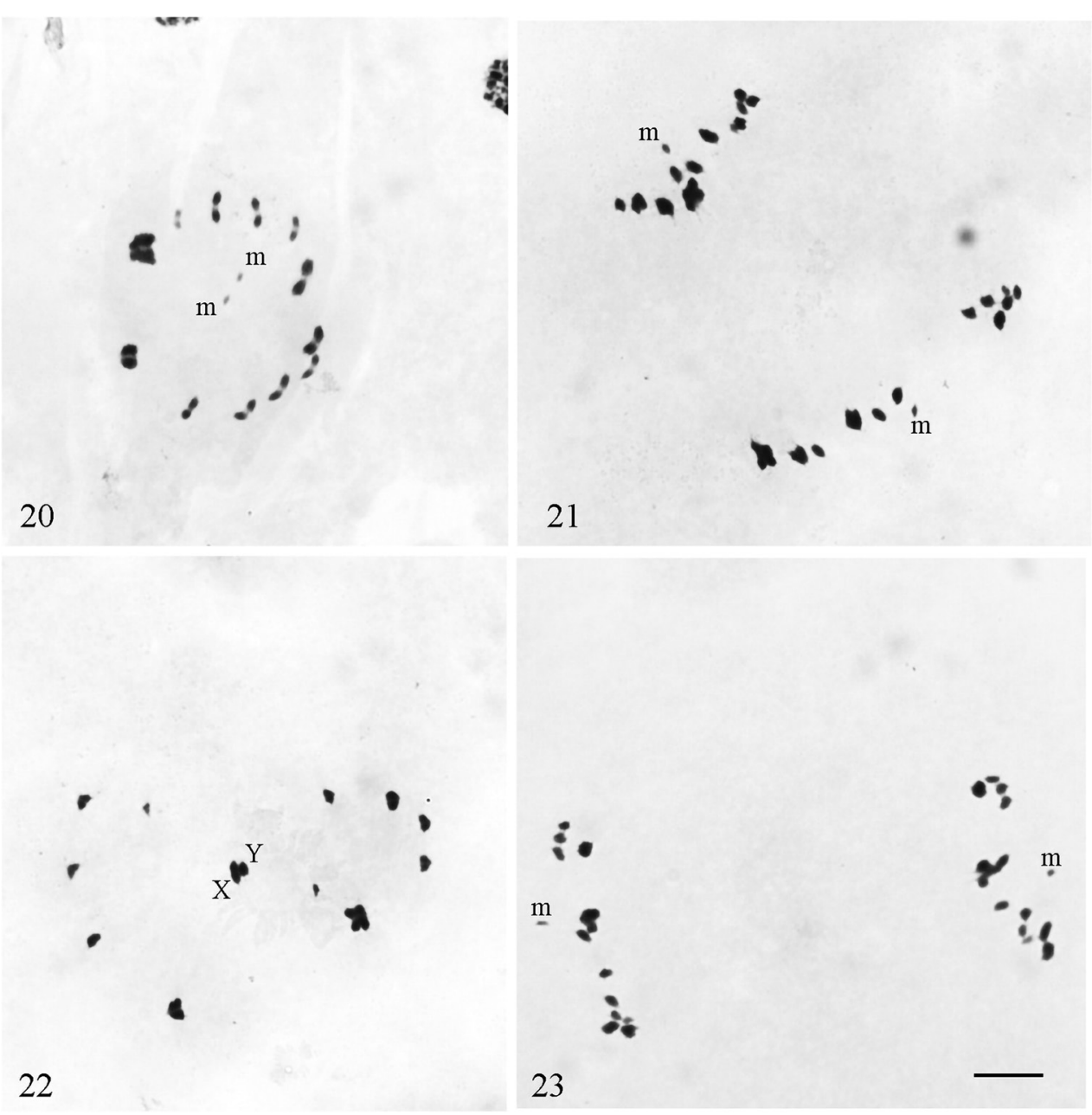

Figures 20-23. Notonecta glauca (testis/ovary) 20, $\mathbf{2}$ I primary spermatocytes: $\mathbf{2 0}$ metaphase I $\mathbf{2} \mathbf{I}$ anaphase I 22, $\mathbf{2 3}$ secondary spermatocytes: $\mathbf{2 2}$ metaphase II with 13 chromosome elements $\mathbf{2 3}$ anaphase II. Scale bar: $10 \mu \mathrm{m}$.

was difficult to distinguish the sex chromosomes in the majority of the meiotic stages. At all the examined AI nuclei, 13 chromosome elements could be counted with the $\mathrm{m}$-chromosomes going ahead of the set (Fig. 21). At MII, a pseudobivalent of the sex chromosomes was placed inside a ring formed by the autosomes; the m-chromosome was indistinguishable (Fig. 22).

Our observations confirm the chromosome formula of $2 n=24(20 \mathrm{~A}+2 \mathrm{~m}+\mathrm{XY})$ and post-reduction of the sex chromosomes reported by Browne (1916) and Halkka (1956) for males of $N$. glauca, collected in England and Finland, respectively. Angus et al. (2004) studied the karyotype of $N$. glauca in midgut cells from both male and female specimens collected in England. He found some specimens with $2 \mathrm{n}=26$ along with 
the regular $2 \mathrm{n}=24$. Our observations of mitotic metaphase plates with 26 chromosomes confirm the occasional occurrence of an extra pair of chromosomes, which was interpreted by Angus et al. (2004) as that of the B-chromosomes. In the present study, C-banding technique was performed but it did not provide additional information.

\section{Association between phases of spermatogenesis and developmental stages in Ilyocoris cimicoides and Notonecta glauca}

Our observations of the association between phases of spermatogenesis and developmental stages in $I$. cimicoides and $N$. glauca differ from those published for these species by Papáček and Gelbič (1989) and Papáček and Soldán (1992), respectively (see Table 1). In I. cimicoides, we observed meiotic divisions in instar V, while Papáček and Gelbič (1989) reported the instar V to have spermatids and spermatozoa only. In adults of $N$. glauca, we observed meiotic divisions, while Papáček and Soldán (1992) found only spermatids and spermatozoa. According to our observations, in both $I$. cimicoides and $N$. glauca, males of the same stage of development show different stages of spermatogenesis if they are collected in different seasons (Table 1). For these species, we assume thus that the spermatogenesis phases are not strongly associated with certain developmental stages. It could be speculated that spermatogenesis phases in these species follow the seasonal changes of factors such as temperature and/or photoperiod. There are no publications about the influence of temperature and/or photoperiod on spermatogenesis in heteropteran species. Nevertheless, the influence of these factors on the development and reproduction of Heteroptera has been well documented (Dunbar and Bacon 1972, Ali and Ewiess 1977, Spence et al. 1980, Braman and Pendley 1993, Nagai and Yano 1999, Niva and Takeda 2003, Zerbino et al. 2013, Gusev and Lopatina 2018, Santos et al. 2018). Temperature effect on the development of subspecies Ily-

Table I. Stages of spermatogenesis and spermiogenesis observed in the testes of IV and Vth instars and adult of $I$. cimicoides and $N$. glauca.

\begin{tabular}{|c|c|c|c|c|}
\hline \multirow[t]{2}{*}{$\begin{array}{l}\text { Developmental stage } \\
\end{array}$} & \multicolumn{2}{|c|}{ Ilyocoris cimicoides } & \multicolumn{2}{|c|}{ Notonecta glauca } \\
\hline & $\begin{array}{l}\text { After Papáček and } \\
\text { Gelbič (1989) }\end{array}$ & Present data & $\begin{array}{l}\text { After Papáček and } \\
\text { Soldán (1992) }\end{array}$ & Present data \\
\hline Instar III & $\begin{array}{c}\text { primary spermatocytes } \\
\text { and as result of MI - } \\
\text { secondary spermatocytes }\end{array}$ & spermatogonial stages & primary spermatocytes & spermatogonial stages \\
\hline Instar IV & $\begin{array}{l}\text { primary spermatocytes } \\
\text { and as result of MI - } \\
\text { secondary spermatocytes }\end{array}$ & $\begin{array}{l}\text { spermatogonial stages and } \\
\text { meiotic prophase stages }\end{array}$ & $\begin{array}{l}\text { primary spermatocytes } \\
\text { and as result of MI - } \\
\text { secondary spermatocytes }\end{array}$ & spermatogonial stages \\
\hline \multirow[t]{2}{*}{ Instar V } & \multirow{2}{*}{$\begin{array}{l}\text { collected in the end of } \\
\text { the summer - bundles of } \\
\text { spermatozoa }\end{array}$} & $\begin{array}{l}\text { collected in July and August } \\
\text { - from PMI to telophase II }\end{array}$ & \multirow{2}{*}{$\begin{array}{l}\text { disappearance "of the } \\
\text { zone of spermatogonia" } \\
\text { (the end of the } \\
\text { spermatogonial divisions) }\end{array}$} & \multirow{2}{*}{$\begin{array}{c}\text { spermatogonial stages } \\
\text { and meiotic prophase } \\
\text { stages }\end{array}$} \\
\hline & & $\begin{array}{l}\text { collected in September - } \\
\text { spermatids/spermatozoa }\end{array}$ & & \\
\hline \multirow[t]{2}{*}{ Adult } & \multirow[t]{2}{*}{ mature spermatozoa } & \multirow[t]{2}{*}{ spermatids/spermatozoa } & \multirow{2}{*}{$\begin{array}{l}\text { No information on the } \\
\text { month of collection - } \\
\text { spermatids/spermatozoa }\end{array}$} & $\begin{array}{c}\text { collected in July - from } \\
\text { MI to AII }\end{array}$ \\
\hline & & & & $\begin{array}{l}\text { collected in September - } \\
\text { spermatids/spermatozoa }\end{array}$ \\
\hline
\end{tabular}




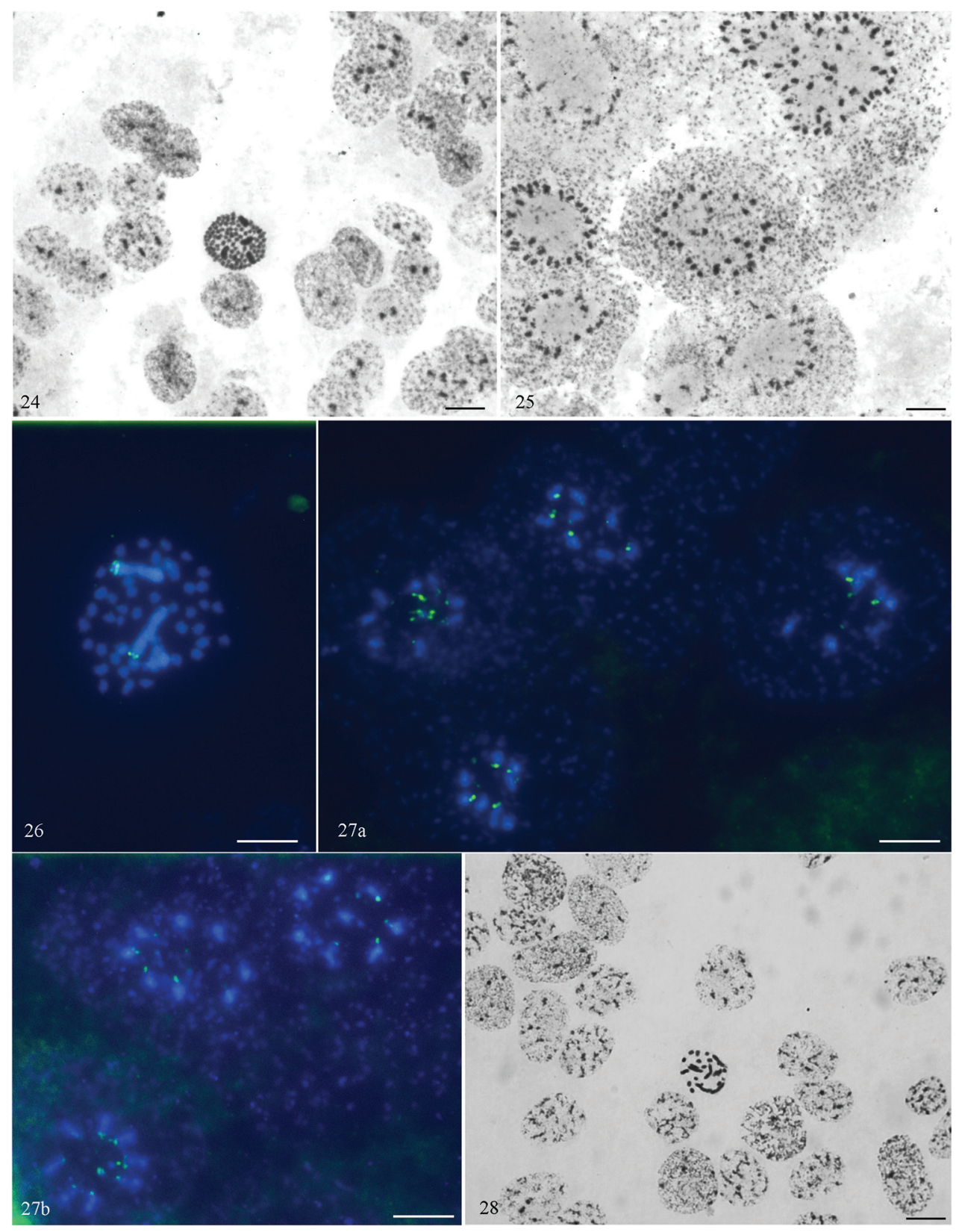

Figures 24-28. Ilyocoris cimicoides and Notonecta glauca (ovarioles): Schiff-Giemsa $(\mathbf{2 4}, \mathbf{2 5}, \mathbf{2 8})$ and FISH with $18 \mathrm{~S}$ rDNA $(\mathbf{2 6}, \mathbf{2 7})$ 24-27 Ilyocoris cimicoides: 24 interphase trophocytes with 2 and 4 heteropycnotic elements, and a metaphase tetraploid trophocyte $\mathbf{2 5}$ interphase trophocytes with 16 and about 32 heteropycnotic elements $2618 \mathrm{~S}$ rDNA signals on the sex chromosomes in a oogonial diploid metaphase plate $\mathbf{2 7}$ a, b $18 \mathrm{~S}$ rDNA signals on the heteropycnotic elements in interphase octoploid trophocytes $\mathbf{2 8}$ Notonecta glauca: interphase trophocytes and a mitotic metaphase diploid trophocyte. Scale bars: $10 \mu \mathrm{m}$. 
ocoris cimicoides exclamationis (Scott, 1874) from Japan has also been reported (Kaneda and Yoshiyasu 2007). We have no data on the environmental factors in the collection sites; therefore, the present study cannot contribute to understanding the influence of environmental factors on the spermatogenesis in the studied species. Nevertheless, for practical purposes, we assume that in Bulgaria (in regions at less than $800 \mathrm{~m}$ a.s.l.) and probably on the Balkan Peninsula, July is the most appropriate month for collecting $I$. cimicoides and $N$. glauca for cytogenetic studies (Table 1).

\section{Trophocyte ploidy in the ovarioles of $N$. glauca and I. cimicoides}

In the ovaries of I. cimicoides and $N$. glauca, we studied the level of ploidy both in mitotic (metaphases) and in interphase trophocytes (nurse cells). Among the trophocytes of $I$. cimicoides, only diploid and tetraploid metaphases were found (Fig. 24). In I. cimicoides, we observed interphase trophocytes with conspicuous heteropycnotic elements, which varied in number from 2 to 32 (Figs 24, 25), almost always an even number. In cells with a higher (8-32) number of elements, the exact counting was often impeded by the clumping of the elements. In ovarian mitosis of I. cimicoides, hybridization signals after FISH for $18 \mathrm{~S} \mathrm{rDNA}$ were found in the telomeric region of the sex chromosomes (Fig. 26). The same hybridization signals were likewise found in heteropycnotic elements of trophocytes (Fig. 27 a, b). This suggests that the heteropycnotic elements found in the trophocytes represent the sex chromosomes. Thus, in I. cimicoides the interphase trophocytes with high number of heteropycnotic elements, i.e. X chromosomes, were highly polyploid ( $2 \mathrm{n}$ was repeated up to 16 times). The situation with $N$. glauca was different. We did not find interphase trophocytes with such conspicuous heteropycnotic bodies (Fig. 28) and we were able to determine the ploidy (2n) only in mitotic trophocytes (Figs 19, 28).

The level of trophocyte ploidy in the ovarioles of I. cimicoides (Nepomorpha) (present study) is the same (16 times increase) as reported for Gerris najas (Gerromorpha) (Choi and Nagl 1977). Much higher level of trophocyte ploidy has been reported for the two hitherto studied species of infraorder Pentatomomorpha: Oncopeltus fasciatus 128 times increase (Cave 1975); Dysdercus intermedins - 124 times increase (Dittmann et al. 1984). The scarce data presently available suggest a tendency for a low level of trophocyte ploidy in basal infraorders (Nepomorpha and Gerromorpha) and a high such level in the more advanced Pentatomomorpha. Data on additional species of the same and other infraorders are needed to confirm this tendency.

\section{Acknowledgements}

The collection of specimens used in this study was partly supported by Research project "Research on model construction of biodiversity conservation in village scale in Mui Ca Mau Biosphere reserve, Vietnam”; Code number: ĐTĐL.CN-26/17. 
The cytogenetic analysis of Diplonychus rusticus was supported by the Bulgarian Ministry of Education and Science, grant KP-06-Russia-18/27.09.2019 of National Fund of Scientific Research.

The cytogenetic analysis of Ilyocoris cimicoides and Notonecta glauca was supported by the Bulgarian Ministry of Education and Science under the National Research Programme "Young scientists and postdoctoral students" approved by DCM \# 577 / 17.08.2018.

We are grateful to M. Todorov for the help with collecting the Bulgarian material for this study.

We thank V. Kuznetsova and V. Evtimova for the useful help to improve the language and the text of the manuscript.

We kindly thank the subject editor S. Nokkala and the reviewers V. Lukhtanov, C. Nokkala and an anonymous reviewer for the valuable criticism and advice on how to improve the text and the illustrations.

\section{References}

Ali M, Ewiess MA (1977) Photoperiodic and temperature effects on rate of development and diapause in the green stink bug, Nezara viridula L. (Heteroptera: Pentatomidae). Zeitschrift für angewandte Entomologie 84: 256-264. https://doi.org/10.1111/j.1439-0418.1977. tb04286.x

Angus RB, Kemeny CK, Wood EL (2004) The C-banded karyotypes of the four British species of Notonecta L. (Heteroptera: Notonectidae). Hereditas 140(2): 134-138. https://doi. org/10.1111/j.1601-5223.2004.01815.x

Angus RB, Jeangirard C, Stoianova D, Grozeva S, Kuznetsova VG (2017) A chromosomal analysis of Nepa cinerea Linnaeus, 1758 and Ranatra linearis (Linnaeus, 1758) (Heteroptera, Nepidae). Comparative Cytogenetics 11(4): 641-657. https://doi.org/10.3897/ CompCytogen.v11i4.14928

Bawa SR (1953) Studies on insect spermatogenesis. I. Hemiptera-Heteroptera. The sex chromosomes and cytoplasmic inclusions in the male germ cells of Laccotrephes maculatus Fabr. and Sphaerodema rusticum Fabr. Research Bulletin of the East Panjab University 39: 181-192.

Biliński SM, Ksiażkiewicz-Kapralska M, Štys P (1990) Unusual organization of the tropharium in the telotrophic ovarioles of an insect, Saldula saltatoria. Tissue and Cell 22(2): 213-219. https://doi.org/10.1016/0040-8166(90)90023-3

Braman SK, Pendley AF (1993) Temperature, photoperiod, and aggregation effects on development, diapause, reproduction, and survival in Corythuch a cydoniae (Heteroptera: Tingidae). Journal of Entomological Science 28(4): 417-426. https://doi.org/10.18474/0749-8004-28.4.417

Browne EN (1916) A comparative study of the chromosomes of six species of Notonecta. Journal of Morphology 27(1): 119-161. https://doi.org/10.1002/jmor.1050270105

Castanhole MM, Pereira LL, Souza HV, Bicudo HE, Costa LA, Itoyama MM (2008) Heteropicnotic chromatin and nucleolar activity in meiosis and spermiogenesis of Limnogonus aduncus (Heteroptera, Gerridae): a stained nucleolar organizing region that can serve as a model for 
studying chromosome behavior. Genetics and Molecular Research 7: 1398-1407. https:// doi.org/10.4238/vol7-4gmr527

Cave MD (1975) Absence of ribosomal DNA amplification in the meroistic telotrophic ovary of the large milkweed bug, Oncopeltus fasciatus. Journal of Cell Biology 66: 461-469. https://doi.org/10.1083/jcb.66.3.461

Chen P-P, Nieser N, Zettel H (2005) The Aquatic and Semiaquatic Bugs (Insecta: Heteroptera: Nepomorpha \& Gerromorpha) of Malesia. Fauna Malesiana Handbook 5 Brill NV, Academic Publishers, Leiden, 546 pp.

Choi C, Nagl W (1977) Patterns of DNA and RNA synthesis during the development of ovarian nurse cells in Gerris najas (Heteroptera). Developmental Biology 61: 262-272. https:// doi.org/10.1016/0012-1606(77)90297-4

Dittmann F, Hörner R, Engels W (1984) Endoploidization of tropharium nuclei during larval development and the first gonocycle in Dysdercus intermedins (Heteroptera). International Journal of Invertebrate Reproduction and Development 7(5): 279-290. https://doi.org/1 0.1080/01688170.1984.10510103

Divaz N (1915) Die Spermatogenese von Naucoris cimicoides. Zoologischer Anzeiger 32: 50-62.

Dumser JB (1980) The regulation of spermatogenesis in insects. Annual Review of Entomology. 25(1): 341-369. https://doi.org/10.1146/annurev.en.25.010180.002013

Dunbar DM, Bacon OG (1972) Influence of temperature on development and reproduction of Geocoris atricolor, G. pallens, and G. punctipes (Heteroptera: Lygaeidae) from California. Environmental Entomology 1(5): 596-599. https://doi.org/10.1093/ee/1.5.596

Eshenberg KM, Dunlap HL (1966) The histology and histochemistry of oogenesis in the water strider, Gerris remigis Say. Journal of Morphology 118: 297-316. https://doi.org/10.1002/ jmor.1051180302

Fent M, Kment P, Camur-Elipek B, Kirgiz T (2011) Annotated catalogue of Enicocephalomorpha, Dipsocoromorpha, Nepomorpha, Gerromorpha, and Leptopodomorpha (Hemiptera: Heteroptera) of Turkey, with new records. Zootaxa 2856(1): 1-84. https://doi. org/10.11646/zootaxa.2856.1.1

Gillot C (1995) Insect male mating systems. In: Leather SR, Hardie J (Eds) Insect Reproduction, CRC Press, Boca Raton, 33-55. https://doi.org/10.1201/9781351073608-2

Golub N, Anokhin B, Kuznetsova V (2019) Comparative FISH mapping of ribosomal DNA clusters and TTAGG telomeric sequences to holokinetic chromosomes of eight species of the insect order Psocoptera. Comparative Cytogenetics 13(4): 403-410. https://doi. org/10.3897/CompCytogen.v13i4.48891

Golub NV, Golub VB, Kuznetsova VG (2018) New data on karyotypes of lace bugs (Tingidae, Cimicomorpha, Hemiptera) with analysis of the $18 \mathrm{~S}$ rDNA clusters distribution. Comparative Cytogenetics 12 (4): 515-528. https://doi.org/10.3897/CompCytogen.v12i4.30431

Grozeva SM, Nokkala S (1996) Chromosomes and their meiotic behavior in two families of the primitive infraorder Dipsocoromorpha (Heteroptera). Hereditas 125: 31-36. https://doi. org/10.1111/j.1601-5223.1996.t01-1-00031.x

Grozeva S, Nokkala S (2003) C-heterochromatin and extra (B) chromosome distribution in six species of the Nabis (Heteroptera, Nabidae) with the modal male karyotype 2n=16+XY. Folia Biologica (Krakow) 51(1/2): 13-22. 
Grozeva S, Anokhin BA, Kuznetsova VG (2015) Bed bugs (Hemiptera). In: Sharachov I (Ed.) Protocols for Cytogenetic Mapping of Arthropod Genomes. Taylor \& Francis Group, CRC press, Boca Raton, 285-326. https://doi.org/10.1201/b17450-9

Grozeva S, Kuznetsova V, Anokhin B (2011) Karyotypes, male meiosis and comparative FISH mapping of $18 \mathrm{~S}$ ribosomal DNA and telomeric (TTAGG) ${ }_{\mathrm{n}}$ repeat in eight species of true bug (Hemiptera, Heteroptera). Comparative Cytogenetics 5(4): 355-374. https://doi. org/10.3897/compcytogen.v5i4.2307

Grozeva S, Kuznetsova VG, Nokkala S (2004) Patterns of chromosome banding in four nabid species (Cimicomorpha, Heteroptera, Nabidae) with high chromosome number karyotypes. Hereditas 140: 1-6. https://doi.org/10.1111/j.1601-5223.2004.01782.x

Grozeva S, Simov N, Nokkala S (2008) Achiasmatic male meiosis in three Micronecta species (Heteroptera: Nepomorpha, Micronectidae). Comparative Cytogenetics 2(1): 73-78.

Grozeva S, Anokhin BA, Simov N, Kuznetsova VG (2019) New evidence for the presence of the telomere motif (TTAGG) $\mathrm{n}$ in the family Reduviidae and its absence in the families Nabidae and Miridae (Hemiptera, Cimicomorpha). Comparative Cytogenetics 13(3): 283-295. https://doi.org/10.3897/CompCytogen.v13i3.36676

Grozeva S, Kuznetsova V, Simov N, Langourov M, Dalakchieva S (2013) Sex chromosome pre-reduction in male meiosis of Lethocerus patruelis (Stål, 1854) (Heteroptera, Belostomatidae) with some notes on the distribution of the species. In: Popov A, Grozeva S, Simov N, Tasheva E (Eds) Advances in Hemipterology. ZooKeys 319: 119-135. https://doi. org/10.3897/zookeys.319.4384

Gusev IA, Lopatina EB (2018) Temperature and Photoperiodic Control of Development in the Green Shield Bug Palomena prasina (L.) (Heteroptera, Pentatomidae) in Leningrad Province. Entomological Review 98(8): 939-955. https://doi.org/10.1134/S0013873818080018

Halkka O (1956) Studies on mitotic and meiotic cell division in certain Hemiptera under normal and experimental conditions. Annales Academiae Scientiarum Fennicae 32: 1-81.

Heming-van Battum KE, Heming BS (1986) Structure, function and evolution of the reproductive system in females of Hebrus pusillus and H. ruficeps (Hemiptera Gerromorpha, Hebridae). Journal of Morphology 190: 121-167. https://doi.org/10.1002/ jmor. 1051900202

Jande SS (1959) An analysis of the chromosomes in the four species of the family Belostomatidae (Heteroptera, Cryptocerata). Research Bulletin (Natural Sciences) Panjab University 10: 25-34.

Jawale SM, Ranade DR (1990) Morphology of the ovaries of Sphaerodema (Diplonychus) rusticum (Heteroptera, Belostomatidae). Journal of morphology 205(2): 183-192. https://doi. org/10.1002/jmor.1052050207

Kaneda H, Yoshiyasu Y (2007) Effects of temperature on the development and survival of the creeping water bug Ilyocoris cimicoides exclamationis (Scott) (Hemiptera: Naucoridae). Proceedings of the Entomological Society of Washington 109: 689-695.

Kanyukova E (2006) Aquatic Heteroptera (Nepomorpha, Gerromorpha) fauna of Russia and neighbouring regions. Dal'nauka, Vladivostok, 296 pp. [In Russian]

Kuznetsova VG, Grozeva SM, Nokkala S, Nokkala C (2011) Cytogenetics of the true bug infraorder Cimicomorpha (Hemiptera, Heteroptera): a review. ZooKeys 154: 31-70. https:// doi.org/10.3897/zookeys.154.1953 
Lanzone C, Souza MJD (2006) Chromosome complement and meiosis in three species of the Neotropical bug genus Antiteuchus (Heteroptera, Pentatomidae, Discocephalinae). Genetics and Molecular Biology 29(1): 49-55. https://doi.org/10.1590/S1415-47572006000100011

Linnavuori RE, Hosseini R (2000) Heteroptera of Guilan with remarks on species of the adjacent areas. Part I. Nepomorpha, Gerromorpha, Leptopodomorpha, Cimicomorpha: Nabidae, Anthocoridae, Cimicidae, Microphysidae. Rasht: Guilan University Press, 94 pp.

Lukhtanov VA, Efetov KA, Dantchenko AV (2019) Karyotype reinvestigation does not confirm the presence of two cryptic species and interspecific hybridization in the Polyommatus (Agrodiaetus) damocles complex in the Crimea (Lepidoptera, Lycaenidae). Comparative Cytogenetics 13(3): 311-319. https://doi.org/10.3897/CompCytogen.v13i3.46777

Ma WK, Ramaswamy SB (1987) Histological changes during ovarian maturation in the tarnished plant bug, Lygus lineolaris (Palisot de Beauvois) (Hemiptera: Miridae). International Journal of Insect Morphology and Embryology 16(5-6): 309-322. https://doi. org/10.1016/0020-7322(87)90003-1

Michalik A, Szklarzewicz T, Wegierek P, Wieczorek K (2013) The ovaries of aphids (Hemiptera, Sternorrhyncha, Aphidoidea): morphology and phylogenetic implications. Invertebrate Biology 132(3): 226-240. https://doi.org/10.1111/ivb.12026

Nagai K, Yano E (1999) Effects of temperature on the development and reproduction of Orius sauteri (Poppius) (Heteroptera: Anthocoridae), a predator of Thrips palmi Karny (Thysanoptera: Thripidae). Applied Entomology and Zoology 34(2): 223-229. https://doi. org/10.1303/aez.34.223

Niva CC, Takeda M (2003) Effects of photoperiod, temperature and melatonin on nymphal development, polyphenism and reproduction in Halyomorpha halys (Heteroptera: Pentatomidae). Zoological Science 20(8): 963-971. https://doi.org/10.2108/zsj.20.963

Nokkala S, Nokkala C (1999) Chromosomes in two bug species of Hebrus (Hebridae, Heteroptera). The occurrence of neo-XY sex chromosome system in Heteroptera. Caryologia 52(1-2): 27-30.

Pantel J, Sinety R de (1906) Les cellules de la ligne'e male chez le Notonecta glauca L. La Cellule 23: 87-303.

Papáček M, Gelbič I (1989) Development of the male internal reproductive system in the saucer bug (Ilyocoris cimicoides L.) (Heteroptera, Naucoridae). In: Tonner M, Soldán T, Bennettová B (Eds) Regulation of Insect Reproduction IV. Proceedings of a symposium held in Žinkovy, September 1987. Academia, Praha, 125-140.

Papáček M, Soldán T (1987) Development of the female reproductive system of Notonecta glauca L. (Heteroptera, Notonectidae) and the life cycle in South Bohemia. Acta Entomologica Bohemoslovaca 84: 161-180.

Papáček M, Soldán T (1992) Development of the male internal reproductive system in Notonecta glauca (Heteroptera, Notonectidae). In: Bennettová B, Gelbič I, Soldán T (Eds) Advances in Regulation of Insect Reproduction. Institute of Entomology, Czech Academy of Science, České Budějovice, 199-211.

Papáček M, Soldán T, Truhlářová I (1997) Development of the female internal reproductive system in Ilyocoris cimicoides L. (Heteroptera, Nepomorpha: Naucoridae). Acta Societatis Zoologicae Bohemicae 61: 77-84.

Papeschi AG (1992) Estudios citogenéticos y evolutivos en Heteroptera. Tesis Doctoral, Universidad de Buenos Aires. 
Papeschi AG, Bressa MG (2006) Evolutionary cytogenetics in Heteroptera. Journal of Biological Research 5: 3-21.

Pendergrast JG (1957) Studies on the reproductive organs of the Heteroptera with a consideration of their bearing on classification. Transactions of the Royal Entomological Society of London 109(1): 1-63. https://doi.org/10.1111/j.1365-2311.1957.tb00133.x

Polhemus DA, Polhemus JT (2013) Guide to the aquatic Heteroptera of Singapore and Peninsular Malaysia. X. Infraorder Nepomorpha - Families Belostomatidae and Nepidae. Raffles Bulletin of Zoology 61(1): 25-45.

Polhemus JT (1995) Family Belostomatidae Leach, 1815 - giant water bugs, electric light bugs, toe biters. In: Aukema B, Rieger C (Eds) Catalogue of the Heteroptera of the Palaearctic Region (Vol. 1). Enicocephalomorpha, Dipsocoromorpha, Nepomopha, Gerromorpha and Leptopodomorpha. Wageningen, Netherlands: Entomological Society, Ponsen \& Looijen, 19-23.

Santos ÍTBFD, Pinheiro HSS, Santos VBD, Santana LKND, Poderoso JCM, Riberio GT (2018) Effects of temperature on the development of Podisus nigrispinus (Heteroptera: Pentatomidae): implications for mass rearing. Florida Entomologist 101(3): 458-463. https:// doi.org/10.1653/024.101.0303

Satomura K, Osada N, Endo T (2019) Achiasmy and sex chromosome evolution. Ecological Genetics and Genomics 13: 100046. https://doi.org/10.1016/j.egg.2019.100046

Simiczyjew B, Ogorzalek A, Štys P (1996) Organization of the trophic chamber in the telotrophic ovarioles of Nepa cinerea and Aradus pictus (Hemiptera, Heteroptera). Zoologica Poloniae 41: 145-158.

Simiczyjew B, Ogorzalek A, Štys P (1998) Heteropteran ovaries: variations on the theme. Folia Histochemica et Cytobiologica 36(4): 147-156.

Spence JR, Spence DH, Scudder GGE (1980) The effects of temperature on growth and development of water strider species (Heteroptera: Gerridae) of central British Columbia and implications for species packing. Canadian Journal of Zoology 58(10): 1813-1820. https://doi.org/10.1139/z80-248

Steopoe I (1929) La spermatogenese chez Naucoris cimicoides. Comptes rendus hebdomadaires des séances et mémoires de la Société de biologie, Paris 102: 1116-1118.

Stoianova D, Grozeva S, Simov N, Kuznetsova V (2015) Achiasmate male meiosis in two Cymatia species (Hemiptera, Heteroptera, Corixidae). In: Lukhtanov VA, Kuznetsova VG, Grozeva S, Golub NV (Eds) Genetic and cytogenetic structure of biological diversity in insects. ZooKeys 538: 95-104. https://doi.org/10.3897/zookeys.538.6722

Štys P, Büning J, Biliński SM (1998) Organization of the tropharia in the telotrophic ovaries of the dipsocoromorphan bugs Cryptostemma alienum Herrich-Schaeffer and C. carpaticum Josifov (Heteroptera: Dipsocoridae). International Journal of Insect Morphology and Embryology 27(2): 129-133. https://doi.org/10.1016/S0020-7322(97)00025-1

Ueshima N (1979) Hemiptera II: Heteroptera. In: John B (Ed.) Animal Cytogenetics. Gebrüder Borntraeger, Berlin-Stuttgart, 117pp.

White MJD (1973) Animal Cytology and Evolution. Cambridge University Press, 961 pp.

Zerbino MS, Altier NA, Panizzi AR (2013) Effect of photoperiod and temperature on nymphal development and adult reproduction of Piezodorus guildinii (Heteroptera: Pentatomidae). Florida Entomologist 96(2): 572-583. https://doi.org/10.1653/024.096.0223 